NBER WORKING PAPER SERIES

\title{
MARKET DISTORTIONS WHEN AGENTS ARE BETTER INFORMED: THE VALUE OF INFORMATION IN REAL ESTATE
}

\author{
Steven D. Levitt \\ Chad Syverson \\ Working Paper 11053 \\ http://www.nber.org/papers/w11053 \\ NATIONAL BUREAU OF ECONOMIC RESEARCH \\ 1050 Massachusetts Avenue \\ Cambridge, MA 02138 \\ January 2005
}

We would like to thank Gary Becker, David Card, Roland Fryer, Edward Glaeser, Michael Greenstone, Jens Ludwig, Chris Mayer, Tobias Moskowitz, Kevin Murphy, Derek Neal, François Ortalo-Magné, Canice Prendergast, Phil Reny, and Andrei Shleifer for helpful discussions and advice. Elias Bruegmann provided truly outstanding research assistance. Thomas Fumo aided us in obtaining the data. Financial support provided by the National Science Foundation. Correspondence can be addressed to either of the authors at Department of Economics, University of Chicago, 1126 E. 59th Street, Chicago, IL 60637. The views expressed herein are those of the author(s) and do not necessarily reflect the views of the National Bureau of Economic Research.

(C) 2005 by Steven D. Levitt and Chad Syverson. All rights reserved. Short sections of text, not to exceed two paragraphs, may be quoted without explicit permission provided that full credit, including $\odot$ notice, is given to the source. 
Market Distortions when Agents are Better Informed: The Value of Information in Real Estate Transactions

Steven D. Levitt and Chad Syverson

NBER Working Paper No. 11053

January 2005

JEL No. D8, L1, L8, R2, R3

\begin{abstract}
$\underline{\text { ABSTRACT }}$
Agents are often better informed than the clients who hire them and may exploit this informational advantage. Real-estate agents, who know much more about the housing market than the typical homeowner, are one example. Because real estate agents receive only a small share of the incremental profit when a house sells for a higher value, there is an incentive for them to convince their clients to sell their houses too cheaply and too quickly. We test these predictions by comparing home sales in which real estate agents are hired by others to sell a home to instances in which a real estate agent sells his or her own home. In the former case, the agent has distorted incentives; in the latter case, the agent wants to pursue the first-best. Consistent with the theory, we find homes owned by real estate agents sell for about 3.7 percent more than other houses and stay on the market about 9.5 days longer, even after controlling for a wide range of housing characteristics. Situations in which the agent's informational advantage is larger lead to even greater distortions.
\end{abstract}

Steven D. Levitt

Department of Economics

University of Chicago

1126 East 59th Street

Chicago, IL 60637

and NBER

slevitt@uchicago.edu

Chad Syverson

Department of Economics

University of Chicago

1126 East 59th Street

Chicago, IL 60637

and NBER

syverson@uchicago.edu 


\section{Introduction}

Because of specialization, individuals rely heavily on the advice of experts in making decisions. For activities as varied as medical treatment, repairing a car, legal advice, planning for retirement, or selling a home (to name just a few), there are experts with particular skills, knowledge, and experience willing to provide their services.

A defining characteristic of transactions involving the hiring of an expert is the informational advantage enjoyed by the expert relative to the client seeking advice. As a result of this private information, expert agents may mislead their clients by exaggerating the costs or difficulty of a solution, providing unneeded services, or otherwise distorting the information to maximize the expert's own payoff. For example, a lawyer may argue that his services are necessary in preparing a simple will, even though the lawyer would use the same off-the-shelf software a client could buy. A car mechanic may suggest overhauling the entire engine when only a small part needs replacing. A travel agent may only mention flights on airlines which pay the highest commission rates to travel agents for booking.

In this paper, we focus on the relationship between a real estate agent and a home seller. The real estate agent is likely better informed about the value of the house and the state of the local housing market than is the seller. Because of the particular form of residential real estate contracts, the real estate agent receives only a small fraction of the purchase price of a home, but bears much of the cost of selling the house (e.g. expenditures on advertising and marketing, showing the home to prospective buyers, and hosting open houses), inducing a misalignment of incentives between the seller and agent. ${ }^{1}$ The agent has strong incentives to sell a house quickly, even at a substantially lower price, and thus may encourage clients to accept sub-optimally low offers too quickly. As in Crawford and Sobel (1982), the homeowner may rationally follow this advice, despite being fully cognizant of the agent's desire to mislead because the incentives of the

\footnotetext{
${ }^{1}$ An interesting question, to which we turn in Section VI, is why the existing contractual arrangements persist in light of this distortion.
} 
home seller and the agent are well-enough aligned that on net the home seller can benefit from the agent's superior information, although in some instances the agent will distort information in a way that hurts the home seller.

Real estate transactions provide an unusually attractive setting to test the impact of information distortion by experts. Unlike many experts (e.g. surgeons), real estate agents not only provide their services to clients, but also sell their own homes. When a real estate agent sells his own home, he is residual claimant on the full surplus from the sale and thus has optimal incentives. By comparing sale prices and time on the market for homes in which the agent is hired by a client versus when the agent sells his or her own home (and controlling for other factors), we have a simple test of the distortions induced by the private information of experts.

Our paper builds on a small empirical literature in this area. Hubbard $(1998,2002)$ analyzes data from the California vehicle inspection emission market and finds that inspection suppliers tend to let vehicles pass inspections, even though they would incur a short-run benefit from repairing those that fail — the reason being that lenient inspections are rewarded with repeat business. Gruber and Owings (1996) provide tantalizing evidence of how physicians may distort decisions to further their own interests. Doctors in areas with declining birth rates are found to be much more likely to perform caesarian sections than are doctors in growing areas. Gruber and Owings interpret this result as possible evidence that excess capacity leads doctors to induce demand for more expensive services from their clients. The research most similar to our work is Munneke and Yavas (1997), which compares sales brokered by RE/MAX real estate agents to those of other real estate agents. At RE/MAX, agents pay a fixed fee and keep the full commission, as opposed to splitting the commission with the agency. In their model, however, they do not focus on the information problem we consider, and indeed predict (and find) no difference in prices and time on the market for RE/MAX agents versus others (although their data 
set is small, giving the tests low power). In addition, agents working for RE/MAX are likely to be a highly selected sample of the most productive agents. ${ }^{2}$

Using a data set of nearly 100,000 home sales, of which roughly 3,300 are agent-owned, we find that agent-owned homes sell for about 3.7 percent (or roughly $\$ 7700$ at the median sales price) more than comparable houses and stay on the market an extra 9.5 days (about 10 percent) longer, even after controlling for a wide array of house and neighborhood characteristics.

Agent-induced distortions are largest when agents enjoy the greatest informational advantage, providing further evidence in favor of the theory. We examine three different dimensions along which the agent's advantage might vary. First, we stratify the sample as a function of how heterogeneous the housing stock is on a particular city block. Greater heterogeneity is likely to increase the agent's informational advantage by reducing the availability to the non-agent homeowner of directly comparable prior home sales. We find that on houses on blocks in the upper-third of our sample in terms of heterogeneity, agents get 4.3 percent more for their houses and stay on the market an extra 9.5 days. In contrast, in the third of the sample where houses on the block are most alike, agents obtain only 2.3 percent more for their houses and time on the market is not significantly different. Second, the rise of the internet has made it much easier for sellers to directly observe the characteristics of other houses on the market and to find recent transaction prices, reducing the informational advantage or realtors. Consistent with the theory, in the period 1992-1995, observationally equivalent agent homes sold for 4.9 percent more than those of their clients and stayed on the market over two weeks longer. From 20002002, in contrast, agents obtained only 2.9 percent more for their houses and stayed on the market 2.5 days longer. Finally, in the case where the buyer is not represented by a realtor, the seller's realtor may have a greater ability to determine the sale price. We find that the absence of a buyer's agent has no impact on the sale price of client homes, but is associated with a 1.7 percent-

${ }^{2}$ Germaise and Moskowitz (2004) analyze a different type of information asymmetry in commercial real estate transactions. Our results also contribute to a growing literature (e.g. Genesove and Mayer 1997, 
higher sale price when the realtor sells his own house. This finding suggests that the realtor successfully exploits uninformed buyers when selling his or her own house, but does not reap the available gain for clients (perhaps because tough bargaining might jeopardize a deal being reached).

All of the empirical findings are consistent with agents distorting information to mislead clients, but are difficult to reconcile with most other plausible theories. If realtor homes are more attractive to buyers on unobservable dimensions (e.g., realtors know better what features the market values or invest more in maintenance of their houses), the higher house price can be explained, but the longer time on the market is puzzling. Likewise, if agents exert less effort in selling their clients' houses than their own (the typical principal-agent story), agents would sell their houses for higher prices, but should sell their own homes more quickly, contrary to the evidence. Another possible explanation-agents having systematically lower discount rates than typical home sellers - would reproduce our most basic results qualitatively, but is insufficient to explain either the size of the differences (a 140 percent annual discount rate would be necessary to match the data) or why the distortions are greatest when the informational advantage is most extreme.

The structure of the paper is as follows. Section II discusses the theory underlying the paper's empirical analysis. Section III introduces the data used. Sections IV and V present the empirical analysis, and Section VI discusses the results and concludes.

\section{The Underlying Theory}

Our analysis of the relationship between a real estate agent and a home seller is predicated on the idea that the realtor has better information about the local real estate market than the home seller. The home seller would like to truthfully elicit the realtor's private

\footnotetext{
Taylor 1999, and Merlo and Ortalo-Magné 2004) analyzing time on the market.
} 
information, but it is neither observable nor verifiable to a third party. The standard contractual form in residential real estate involves the realtor paying much of the marginal cost of marketing the home, but receiving only a small fraction of the marginal proceeds of the sale. Thus, the realtor is willing to accept a lower price for the house than the homeowner in order to sell more quickly. A rational homeowner will take the agent's distorted incentives into account and discount appropriately the agent's advice regarding whether a particular offer should be accepted or rejected. Nonetheless, as we formally derived in an earlier version of this paper (Levitt and Syverson 2002), if the agent is sufficiently better informed, the agent's optimal strategy is to advise the homeowner to accept any offer that is in the best interest of the agent to accept, and the homeowner will follow the agent's advice. ${ }^{3}$ Just as in Crawford and Sobel (1982), despite the fact the homeowner knows the agent's recommendation is distorted, the best the poorly informed homeowner can do is to follow the advice. ${ }^{4}$ Thus, the primary predictions of the theory are that (1) for two identical houses, one owned by a real estate agent and the other owned by a client of the real estate agent, the real estate agent's home will stay on the market for a longer period of time and sell for a higher price, and (2) the greater the informational advantage of the real estate agent, the larger these two differences will be.

\footnotetext{
${ }^{3}$ Note that in this setup, the agent cannot credibly convey any information beyond a simple recommendation to either accept or reject the offer. Any message that attempted to further signal the intensity of the agent's preferences is cheap talk. For any offer that is high enough that the agent would like the seller to accept, the agent will have the incentive to falsely portray the offer as being extremely high, even if it is just above the acceptability cutoff. As consequence, the seller will ignore such information (Crawford and Sobel 1982). If we were to allow cash transfers from the agent to the seller, this would provide a means for the agent to convey more information about the attractiveness of the offer. When a really good offer arrives, the agent could credibly signal this by offering to make an additional payment to the seller if the offer is accepted.

${ }^{4}$ Since Crawford and Sobel (1982), a rich theoretical literature has developed that analyzes strategic information transmission. Theory that is particularly relevant to our analysis includes recent work on the role of experts by Taylor (1995), Levy (2000), and Krishna and Morgan (2001). For surveys of the broader literature, see Kennan and Wilson (1991) and Riley (2001). There is also a great deal of work addressing how contracts are structured to encourage agents to exert the optimal amount of effort (e.g., Grossman and Hart 1983, Sappington 1991). Prendergast (2002) argues that the empirical evidence supporting the hypothesized tradeoff between risk and effort is tenuous.
} 
The extent of the distortion induced by misaligned agent incentives may be considerable. Real estate agents typically bear a substantial fraction of the marketing costs involved with a home sale: advertising, accompanying potential buyers on visits to the home, conducting open houses, and negotiating offers. Typically, however, the agent receives only about 1.5 percent of each marginal dollar of the price for which the house sells. (The total share of the sale price that goes to agents is usually 6 percent, split evenly between the buyer's and seller's agents. Of the selling agent's 3 percent, roughly half goes to the agent's firm, leaving 1.5 percent for the agent.) If the combined financial and opportunity cost to the agent of selling a house were $\$ 200$ per week, then the agent would be indifferent between selling the house today and waiting one more week and receiving an offer $\$ 13,333$ higher with certainty. The homeowner, on the other hand, would much prefer to wait a week and take the higher offer. On a $\$ 300,000$ house, the homeowner's one week return from waiting would be over four percent. Another way of putting into perspective just how distorted are the agent's incentives is to compare real estate to sharecropping, where some have argued that the contractual form leads to important distortions (e.g. Shaban 1987). In the typical sharecropping arrangement, the output is split 50-50 between the land owner and the sharecropper; in real estate, the seller's agent receives only 1.5 percent of the profit on the margin. Furthermore, most sharecropping arrangements involve a repeated game, whereas home sales are often one-shot deals.

\section{Data Used in the Analysis}

The data we use encompass nearly 100,000 home sales in suburban Cook County, Illinois. The source of the data is the Multiple Listing Service of Northern Illinois (MLSNI), the clearinghouse through which realtors in the Chicago metropolitan area notify other realtors (and, more recently, the public) of properties for sale. ${ }^{5}$ These data have numerous strengths. First, they

\footnotetext{
${ }^{5}$ Further details about MLSNI can be found at www.mlsni.com. The archived data we utilize in this paper are not publicly available, but can be obtained by any licensed realtor who is part of MLSNI.
} 
cover virtually every house put up for sale in which a seller's agent is hired, regardless of whether the house is eventually sold. Most of the analysis presented below focuses on homes that actually sell, but we are also able to explore whether or not listed homes sell as a check on possible selection biases. Second, the data contain extremely detailed information about every house on the market, including the address, a wide range of housing characteristics, the list price and sale price of the home, a written description of the house's attributes used by the real estate agent in marketing the house, and the key dates regarding the home sale (e.g., when the house goes on the market, the date a contract is signed with a buyer, etc.). Third, the data report whether the real estate agent has an ownership interest in the house, which is critical to our identification strategy.

The MLSNI data do, however, have a number of important flaws and limitations. First, the dataset does not provide any information about homes that are for-sale-by-owner (FSBO). Second, the information in the database is entered by the real estate agents themselves. There is no independent check on the accuracy of the description of the home's attributes. ${ }^{6}$ Also, there are few restrictions on what agents can type into a field in the data base and no requirement that all fields be completed. As a consequence, there are substantial amounts of missing data for some variables (e.g. approximate square footage), some evidence of obvious errors, and a lack of uniformity in the way fields are coded. ${ }^{7}$

Our primary sample is made up of sales of single-family homes that were listed for sale during the period 1992-2002 in 34 Cook County suburbs. These suburbs are the 34 largest Chicago suburbs in which the majority of properties listed for sale are detached single family homes and in which sales of newly constructed homes represent a small fraction of overall sales.

\footnotetext{
${ }^{6}$ For some entries such as listing prices and addresses, there are strong incentives for the agent to enter the correct numbers, since this database is the primary mechanism through which other agents learn what properties are currently for sale.

${ }^{7}$ For instance, we observe over fifty different entries for the field asking the presence or absence of "air conditioning," corresponding to different conventions for abbreviating responses and different types of systems such as wall units, central air, zoned central air, space-pacs, or a combination thereof.
} 
We impose a number of restrictions on the data. We use county tax identification numbers to link listing and sales activity on a given property over time. Properties that are missing tax identification numbers, or have errors in these numbers (for instance, two properties listing the same tax ID number but located in different cities) are dropped from the sample. Any home that sells twice within a three-year period is dropped from the sample due to concerns that the house has been purchased and rehabbed for resale. In the presence of imperfect measures of a house's quality, these repeat transactions may yield particularly misleading results, especially if real estate agents are more likely to be rehabbers than other sellers. ${ }^{8}$ After these initial exclusions, we are left with listings for just under 127,000 homes. About 22 percent of these homes are withdrawn from the market before a sale ever occurs. We eliminate a small number of properties with either very low or high listing prices or sale prices (less than $\$ 50,000$, more than $\$ 3,000,000$, or a price more than five times the median value in that city), and properties with suspicious entries such as those reporting no bathrooms, no kitchen, etc. Finally, in order to estimate all models with a common sample, about 450 listings are removed due to missing data for one or more of the variables included in the hedonic model. This leaves us a final data set with roughly 98,000 home sales. About 3.4 percent of the observations in our data-3330 sales - involve a real estate agent selling his or her own home.

Table 1 presents summary statistics for the data set. The first two columns report the mean and standard deviation of key variables over the entire sample. Columns (3)-(5) show a set of three statistics regarding data variations within city-year cells. Column (3) contains the standard deviations of the variables' within-city-year components; that is, the standard deviation of the residual when the variable is regressed on a set of city-year dummies. Column (4) shows differences between the means of the agent-owned and non-agent-owned home sales within each city-year, and (5) reports the p-value of a test for equality of the means. Columns (6)-(8) report

\footnotetext{
${ }^{8} \mathrm{~A}$ rehabber can get better access to properties and can collect commissions on the property transactions business by becoming a real estate agent. Thus most rehabbers are likely to also have real estate licenses.
} 
data that parallels the information in columns (3)-(5), but presents within-block, rather than cityyear comparisons.

The second through fourth rows of the table contain our primary variables of interest: sale price (in levels and logs) and time on the market. Consistent with the prediction of the model, even on a given block, agent-as-seller homes sell for substantially more $(\$ 48,445$ on average, or 18 percent of the mean sales price ${ }^{9}$ ) and conditional on a sale occurring, remain on the market for almost 15 days longer than other homes. In results not reported here, we also find that a slightly smaller fraction of the agent-owned homes that are put on the market are eventually sold. This reinforces the fact that agent-owned homes take longer to sell. If one computes the average number of days on the market per home sale, including properties that never sell in the numerator, agent-owned houses are on the market 135 days per sale, compared to only 111 for non-agentowned houses, or 22 percent longer. It is clear from the remainder of the table, however, that the attributes and locations of homes owned by agents are systematically different from the nonagent-owned homes. Real estate agents tend to live in homes that are larger, newer, and have greater numbers of amenities like master baths and fireplaces, even compared to other homes on the same block. These systematic differences in housing characteristics highlight the importance of controls in the analysis we carry out. Although we have an extremely rich set of covariates, the possibility remains that realtor-owned properties might be correlated with unobservable characteristics of the housing.

\section{Core Empirical Estimates}

The empirical specification we estimate to predict sale prices and time-on-market that is most fully saturated takes the following form:

It is worth noting, however, that our empirical results are not sensitive to excluding repeat sales.

${ }^{9}$ The skewness of the house price distribution may exaggerate the size of a typical difference. The mean difference in logged sales prices - the primary difference we focus on below-suggests a 12-percent difference in average sales prices. 


$$
y_{h t a}=\beta^{*} A G E N T_{-} O W N E D_{h t}+X_{h t} \gamma+\kappa_{c t}+\lambda_{b}+\varepsilon_{h t},
$$

where $h, t, c$, and $b$ correspond respectively to house, year, city, and city block. The dependent variable $y$ is either a house's logged sales price or days on the market. ${ }^{10}$ The full set of housing characteristics listed in Table 1 are included in $X_{h t}$. In addition, we allow for city-specific variation in annual prices $\left(\kappa_{c t}\right)$, and fixed-effects for each city block $\left(\lambda_{b}\right)$.

Table 2 presents a series of regression results in which the set of control variables is expanded as one moves from left to right. The logged sales price coefficients on agent-owned houses are presented in the top row of numbers, and the corresponding coefficients for days on the market are shown in a lower row. Heteroskedasticity-consistent standard errors are in parentheses. In addition, the bottom row of the table reports the "informational rents" accruing to the realtor, computed as the additional sale price they receive minus the cost of waiting longer to sell. We use an annual discount rate of 20 percent in these calculations - a number that is high, but consistent with the previous research of Genesove and Mayer (1997).

Column (1) includes fixed effects for each city-year pair as well as controls for the subset of our observed housing characteristics that reflect the scale of the house (e.g., number of bedrooms, number of bathrooms, how many cars the garage can hold). Controlling for the scale of the house substantially reduces the estimated impact of agent ownership from the simple within-city mean differences in Table 1 . The sales price difference between agent-owned and non-agent-owned homes is 4.8 percent, almost two-thirds less than the within-city difference obtained before conditioning on scale. Thus the fact that agents live in their cities' larger-thanaverage homes, as seen before in Table 1, is in part responsible for the observed differences in

\footnotetext{
${ }^{10} \mathrm{We}$ have also run other specification variations in the same spirit as the sales price and time-on-market regressions reported here. One variant used homes' original list prices as the dependent variable, since it is possible that agents' information advantage also impacts the way listing prices are set. The other variant estimated a sales hazard model on the probability a particular home sells as a function of observables. This allowed us to directly account for the fact that certain listing episodes are truncated (i.e., pulled off the market) before a sale is ever made. We found in both cases very similar results - qualitatively and quantitatively - to those reported below. Agent-owned homes are put on the market at higher prices than non-agent-owned homes and have longer expected times-to-sale.
} 
sales prices and time on the market. The difference in time on the market is about 17 days, onethird less than the unconditional value in Table 1. Adjusting for the longer time on the market, realtors achieve an extra return of 3.9 percent on their houses. The coefficients on the control variables (which are shown for the complete hedonic specification in Table 3) indicate that as expected, more is better.

A particular concern in testing the hypotheses of the model is that agents live in houses that are especially attractive along dimensions that are difficult for us to observe or quantify. For instance, agents may have good taste, take better care of their houses, or live in houses that have more features desired by potential home buyers (e.g., master bedroom suites, modern kitchens, and so on). Columns (2) and (3) of Table 2 attempt to control for possible differences in quality in two ways.

In column (2), a wide range of housing characteristics are added such as the a variable for the presence of a master bathroom, the number of fireplaces, the presence of air conditioning, the house's age (category), the exterior material (brick, stucco, etc.), and the style of the house (colonial, bungalow, etc.). We also control for the listing agent's total number of sales as a proxy for reputation and experience effects. When these controls are added, the agent-owned coefficient in the sale price equation drops slightly, from 0.048 to 0.042 , while the estimated difference in days on the market falls from 16.89 to 11.03 . Because the gap in time on the market shrinks between column 1 and column 2, the implied informational rents accruing to agent-owned homes falls only half as much as the magnitude of the sale-price gap (i.e. from 3.9 percent to 3.6 percent).

In column (3), we add dummy variables for a large set of keywords and phrases used in the written marketing description of the house. When these descriptors are added, neither coefficient changes by more than 10 percent. Further, this is despite the fact that many descriptors enter into the regression significantly, as indicated in Table 3. Systematic quality differences appear to be responsible for part of the gap between agent-owned and non-agent- 
owned homes sales prices and times-on-market (although most of the difference is explained by broad indicators of age and style rather than by more subtle characteristics picked up by the agents' descriptions).

A way to further remove possible biases due to unobservables is to include block fixed effects, so that identification of the parameters comes from a comparison of sale prices of different homes on the same block, rather than from homes in different areas of a city. Homes on the same block are nearly identical in terms of school quality, crime, proximity to public transportation and parks, etc. As demonstrated in column (4), the $\mathrm{R}^{2}$ of the regressions - and particularly those for time-on-market—jump noticeably when block affects are added, suggesting the presence of important differences across blocks within a city. The estimated sales price and time-on-market impacts of a home being agent-owned, however, see only small and statistically insignificant drops with the inclusion of block fixed effects. The implied price gap between agent-owned and non-agent-owned home sales is 3.7 percent, with agent-owned homes staying on the market 9.5 days longer.

The results of Table 2 suggest that the primary dimension along which agent-owned houses differ from other homes is in terms of scale and readily identifiable amenities such as master baths. Controlling for these factors in Column 1 dramatically lowers the gaps between agent-owned and other houses, relative to the means of the raw data. Including a wide range of other controls, however, accounts for much of the residual variance in sale prices, but has a relatively small impact on the impact of agent-ownership. ${ }^{11}$

\footnotetext{
${ }^{11}$ We have explored two further approaches for quantifying the extent to which remaining unobservables might be biasing our estimates. Following the methodology of Murphy and Topel (1990), under the assumption that variation in our outcome variables that we cannot explain is related to our agent-owned variable in the same way as the variation that we can explain, we can estimate the true coefficients, even if some bias due to unobservables remains in our specifications. Moving from column 2 to column 4 of Table 2, the sale price coefficient falls from 4.2 percent to 3.7 percent as the R-squared of the regression rises from .886 to .958 . Extending that trend over the remaining unexplained variation yields an estimate of 3.4 percent on the agent-owned variable in the sale price regression. The time on the market results, because the R-squared is lower, are slightly more sensitive, yielding an estimated true underlying
} 
The estimated realtor-owned-home coefficient has a plausible magnitude. A 3.7-percent divergence in sales price for the median-priced home in our sample $(\$ 208,000)$ implies a $\$ 7700$ higher sales price for an equivalent agent-owned home. The additional time on the market spent by agent-owned homes is roughly 10 percent of the average listing time. The time-on-market results suggest a partial explanation for Genesove and Mayer's (1997) interesting finding that home sellers in their sample have a high implied discount rate. If our analysis is correct, sellers sell too quickly not only because of impatience, but also because agents "trick" them into doing so.

It is not the case that extra money received by realtors can be explained as fair compensation for waiting longer to sell their house; a 3.7 percent higher sale price in return for a waiting an additional 9.5 days implies a 140 percent annual discount rate. ${ }^{12}$ Even if one uses an extremely high annual discount rate of 20 percent (but one that is consistent with the behavior of home sellers in Genesove and Mayer 1997), then adjusting for the longer time on the market, agent houses sell for the equivalent of 3.2 percent more than the homes of their clients, as shown in the bottom row of Table 2. This represents a crude estimate of the value of the agent's informational advantage, although it will be upwardly biased if agents invest more effort or make a greater financial investment when selling their own homes, as a standard principal-agent model would suggest.

Our results are not easily reconciled with either a model in which realtor houses are more attractive on unobservable dimensions such as good taste in choices of décor by realtors, or by the standard principal-agent model in which realtors exert more effort when selling their own homes. In both models, one would expect realtor homes to sell more quickly, not more slowly. Our

coefficient of 5.7 extra days on the market, compared to our estimate of 9.5 days. A second approach to eliminating unobservables is the inclusion of agent-fixed effects in the specification. With agent-fixed effects, the coefficient on the agent-owned variable in the sale price regression is 2.9 percent (standard error of 0.3 percent) and in the time on the market regression the coefficient is 6.5 days (standard error of 2.3 days).

${ }^{12}$ If $(1+r / 365)^{9.5}=1.037$, then $r=1.398$. 
results, at least in principle, could be a consequence of realtors selling their own homes being less risk averse than their clients or having systematically lower discount rates. We see little reason why realtors should be less risk averse than the typical seller, especially since shocks to housing prices will affect their wealth both via their labor income and the price they could receive for their home. With respect to discount rates, the enormous difference in discount rates required to explain our results make this explanation an unlikely one as well. In addition, neither a risk aversion story nor a discount rate story can explain why, as we demonstrate below, the patterns we observe systematically vary with the extent of the agent's informational advantage.

Table 3 reports the full set of parameters for the control variables included in the regression with block fixed effects. While these are not the primary focus of our analysis, it is reassuring that the coefficients on these characteristics are sensible. For example, all else constant, a house with four bedrooms sells for 6.1 percent more than one with three bedrooms, going from 1.5 to 2.0 baths is worth 1.4 percent, central air is worth 6.8 percent relative to no air conditioning, brick houses sell for an 3.6 percent premium over those with siding, and colonials sell for 8.5 percent more than otherwise identical ranch-style home.

The coefficients on the words used in the written descriptions of the properties are also of some interest. Words that indicate obvious problems with a house, such as "foreclosure," "as-is," "handyman special," etc. are associated with substantially lower sale prices. ${ }^{13}$ Words that correspond to well-defined and desirable attributes of the house that are not otherwise communicated in the property listing, e.g. "granite," "maple," "gourmet," etc., are related to higher sale prices. Among the words that have zero or even negative correlations with prices are some that are superficially positive, but in effect damn with faint praise (like "clean," "quiet," and "youthful"); words and phrases that do not describe particular characteristics of the house (e.g.,

\footnotetext{
${ }^{13}$ Our basic findings regarding agent-owned homes are robust to excluding these problem properties. If we drop any property that has one of the keywords that might indicate a property in unusual disrepair (there are a total of 15,232 such homes in our sample), the estimate on the agent-owner dummy in the sales price
} 
"fantastic," "charming," and "'?); and those that characterize features of the house already covered by other information available in the listing sheet (e.g. "spacious").

\section{How Do Outcomes Vary with the Extent of the Agent's Informational Advantage?}

Further evidence that the explanation of our findings rests on the agent's informational advantage comes from an analysis of subsets of the data across which that advantage is likely to systematically vary. We examine this issue along three different dimensions, reporting the results in Table 4.

The first dimension we analyze is the degree of heterogeneity in the housing stock on the city block where the home is located. In areas with nearly identical homes, sellers can learn much about their own homes' values simply by noting nearby sales prices. When housing stock in an area is very heterogeneous, however, other sales prices convey less information to sellers about their homes' values. We proxy heterogeneity by constructing a Herfindahl index of home styles among houses sold on the block in our sample period. (That is, we sum the squared shares of each housing style on the block.) In order to be included in the analysis, we require at least 3 homes to be sold on the block. Houses are classified into 21 different styles (e.g., ranch, colonial, American four square, prairie, contemporary) using the descriptions in the MLS listing. We then divide blocks into three equally sized groups according to the Herfindahl measure. The coefficient estimates of the impact of an agent-owned home are reported in the panel A of Table 4. In addition, we also report the implied informational advantage of the realtor, where we have adjusted the agent-owner price gap for differences in time on the market using an annual discount rate of 20 percent.

As can be seen in the table, the sales price difference between agent-owned homes and other homes is indeed highest on blocks where the houses are most different. Here, the price

regression is $0.036(0.003)$, essentially the same as that for the full sample. The coefficient in the time-onmarket regression is 9.20 (2.44), also very close to the full-sample result. 
difference is 4.3 percent. The gap is smaller in the moderate-heterogeneity blocks ( 3.9 percent), and smaller still on the low-heterogeneity blocks (2.3 percent-roughly half that of the most dissimilar blocks), all in accordance with the notion that neighborhoods with dissimilar houses present a larger information advantage for realtors. The time on the market differences reflect similar contrasts (though the point estimate is slightly higher for the moderate-heterogeneity blocks than it is for the high-heterogeneity blocks). Agents on the more heterogeneous blocks clearly keep their houses on the market for a longer period than non-agents, while there is no statistically significant time-to-sale gap on those blocks with the most similar houses. Finally, the sizes of agents' implied information advantage in the three sub-samples are in accordance with expectations: it is largest for the most dissimilar blocks but gets progressively smaller as heterogeneity falls. ${ }^{14}$

The second dimension along which we expect to see systematic differences in agents' information advantage relates to the introduction of the internet. In recent years information about house sale prices have become readily available to the general public on the Chicago Tribune website. In addition, sellers can now directly access a limited version of the MLS. There are also web-based services that will predict the market value of a home based on econometric models (e.g. Case and Shiller 1990) and information the seller enters into the program. Because of the improved information dissemination, we expect that the information advantage of realtors has fallen over time. We report in panel B of Table 4 the results from estimating our full hedonic specification on three sub-samples of the data stratified by time period (1992-1995, 1996-1999, and 2000-2002).

\footnotetext{
${ }^{14}$ We have also attempted to measure heterogeneity of housing based upon the measured heterogeneity in the overall observable characteristics of homes sold on the block. To obtain that block-level measure of house heterogeneity, we first regress logged sales prices on a set of city-year dummies and block effects. The residuals from this regression are that portion of home sales prices not driven by temporal or spatial differences in average price levels. These residuals therefore embody between-home differences in observable characteristics, such as the number of rooms, the age of the home, and so on. We use the average squared residual on each block as our measure of block heterogeneity. The results are similar to those obtained using the Herfindahl index based on housing styles.
} 
As expected, the largest average sales price difference between agent-owned and nonagent-owned homes - 4.9 percent — is in the earliest period. This falls by about one-third, to 3.2 percent, during 1996-1999 (where the internet is starting to widely diffuse), and drops again slightly after 1999. The time-on-market differences echo these patterns; agent-owners wait more than two weeks longer before 1996, just over a week longer in the middle period, and two-and-ahalf days longer in 2000-2002. The implied information advantages, shown in the final column, again reflect that agents were more able to act opportunistically in the earlier part of the sample. The information gap is roughly 50 percent higher than in the latter parts of the sample, although indistinguishable between the middle and the end of the sample.

The third dimension along which the informational advantage may vary is with respect to the presence of a buyer's agent. In most transactions, the sellers and buyers are represented by different agents. In some transactions, only the seller has an agent, or the same agent represents both the seller and the buyer. There are three channels through which the absence of an independent agent representing the buyer could enhance the information advantage of the seller's realtor. First, the selling agent would communicate directly with potential home buyers, providing an additional channel through which to affect outcomes (perhaps without the seller's complete knowledge). If a buyer has a realtor, on the other hand, the two realtors talk to each other instead of the opposing clients. Second, a buyer's agent is likely to be better informed than the clients he or she represents. While the incentives of buyers and their agents are not perfectly aligned (buyers' realtors prefer to have deals go through, even if buyers overpay), buyers' agents are nonetheless acting on behalf of buyers and may credibly contradict statements by the selling agents about the current state of the market. Third, and perhaps most importantly, when buyers do not have agents, the selling realtor's commissions double since fees do not have to be split with a buyer's agent. Therefore selling agents have strong incentives to sell to buyers without agents; when realtors sell their own homes, however, the incremental gain of 1.5 percent from 
making a sale with no buyer's agent is only a small portion of the total value of the house. The cost to a realtor of

To test these hypotheses, we re-run our basic specification for the sales price of the home, but add two indicator variables to the specification (as well as interacting these indicators with the agent-owned dummy). One variable indicates the presence of a buyer's agent (a value of zero implies only the seller's agent is involved in the transaction), and the other variable takes a value of one when both a buyer's and seller's agents are involved in the transaction and they belong to the same brokerage company (we observe agents' brokerage affiliations in our data). ${ }^{15}$

The results, which are presented in the panel $\mathrm{C}$ of Table 4, fit nicely with the theoretical predictions. The absence of a buyer's agent has a negligible impact on the sale price when a selling agent is representing a client; the logged price effect (not reported in the table) is 0.0005 with a standard error of 0.002 . When the agent is selling his or her own home, on the other hand, the absence of a buyer's agent is associated with a (statistically significant) 1.9 percent increase in the sale price, raising the agent-owned gap from 3.3 percent to 5.2 percent. One interpretation of this result is that home buyers without agents are less well informed and susceptible to paying higher prices if the seller's realtor wishes to extract the surplus. But, since the selling agent earns twice as much by selling to a buyer without an agent, they do not attempt to extract the surplus for their client at the risk of the deal failing to go through. When the agent sells his or her own home, however, buyers without agents are exploited to the full extent possible since the agent is the residual claimant.

\footnotetext{
${ }^{15}$ Time-on-the-market regressions will not provide meaningful information in this context, since time on the market is a function of the entire history of the house's listing experience, and has little to do with precise identity of the final purchaser and whether that person is represented by an agent or if that agent shares a brokerage with the seller's agent.
} 


\section{Conclusion}

Experts hold valuable information. This information is helpful to those who hire them, but can also be a source of welfare-reducing distortions. In this paper, we examine economic interactions between experts and their clients in a particular industry, residential real estate. The empirical estimates suggest the distortions are non-trivial: agents sell their own homes for 3.7 percent (roughly $\$ 7,700$ ) more than they sell their client's homes, and leave their houses on the market roughly 10 days (10 percent) longer. The greater informational advantage the agent enjoys, the larger the difference between the price and time on the market experience of agents and the clients they represent. The combination of real estate agents' information advantage along with the commission form of the typical real estate contract combine to create distortions from first best. Homeowners are induced by their agents to sell too quickly and at a price that is too low.

Our results are not consistent with a model in which unobservable agent effort is the driving force. While that model may predict higher sales prices for agent-owned homes, it also predicts such homes will sell at least as quickly, the opposite of what we observe. Nor are our results consistent with a model in which reputation effectively disciplines agents. In that model, one would expect to observe no systematic differences between agent-owned homes and those sold by their clients. The gaps we observe are too large to be easily reconciled with systematic differences in degrees of risk aversion or discount factors.

If our hypothesis is correct, it raises the puzzle of why a contractual form that so badly misaligns agent and home-seller incentives arose and persists. One might imagine a better alternative would be similar to the model commonly employed in resale of used automobiles, in which an intermediary purchases used cars and then resells them at a markup to buyers with higher valuations. By purchasing the used cars outright, the intermediary then earns the full markup, rather than a small percentage as with houses. Such a system, however, would appear to be even less efficient than the current set-up for home sales because the carrying costs of a home 
are so great. The implied interest payments on a $\$ 200,000$ home are roughly $\$ 1,000-\$ 1,500$ per month at reasonable interest rates. If it took, say, an average of 3-6 months for an intermediary to turnover a home, this holding could well exceed the distortion we estimate under the current system. Moreover, from a social welfare standpoint, having the house sit empty would be more costly than the distortion created by the current structure, which is merely a transfer from seller to buyer. Thus, giving the intermediary the full marginal benefit is unlikely to be a superior alternative, although intermediate systems that capture elements of both have been proposed (Jares, Larsen, and Zorn 2000). ${ }^{16}$

Another possible contractual arrangement would involve nonlinear commission structures, where the share paid to the agent would grow in the sales price. However, such a structure would be difficult to implement, precisely because the homeowner is less informed than the agent. It is not easy to see how sellers can set effective breakpoints in a nonlinear contract if they have imperfect information about home values and the state of the market. Nonetheless for price levels that are well below the minimum threshold of the home's value, there is no obvious rationale for paying the agent a commission, except for the simplicity of the linear contract. Why, in spite of the obvious flaws, has the current contractual form in real estate remained so pervasive and resistant to change, even as parallel improvements in information have so radically altered the markets and commission structures for travel agents and stock brokers? ${ }^{17}$

If agents' only service to home sellers is the information they provide about valuations and likely offers, it is surprising that more sellers don't more frequently hire an independent appraiser to inform them of the value of their home. An appraiser is disinterested in the final transaction price, which would eliminate the distortions created by the agent's contractual form

\footnotetext{
${ }^{16}$ Interestingly, consignment used car lots exist in some localities. That is, the real estate model has been applied toward used cars, instead of the other way around. These lots usually specialize in low-value automobiles that would otherwise be ignored by traditional used car sellers. It would be interesting to examine why such selling models sometimes arise.
} 
(but could induce moral hazard problems). Furthermore, appraisers can provide this information at a fairly low cost. It may be that appraisers, in their current form, are actually less skilled at valuing homes in a particular area than are local real-estate agents. Nonetheless, this begs the question why this market niche has not arisen. Alternatively, it may be the case that agents provide a bundle of services besides just valuation information, and these services are worth the commission cost despite the distortions highlighted above.

\footnotetext{
${ }^{17}$ Despite the fact that commissions have not shown a secular downward trend, real estate agents may not have fared any better than stock brokers. Hsieh and Moretti (2003) demonstrate that free entry of agents quickly dissipates rents due to rising real estate prices.
} 


\section{References}

Case, Karl, and Robert Shiller. "Forecasting Prices and Excess Returns in the Housing Market." American Real Estate and Urban Economics Association Journal, 18(3), Fall 1990, 253 73.

Crawford, Vincent P. and Joel Sobel. "Strategic Information Transmission." Econometrica, 50(6), $1982,1431-51$.

Genesove, David and Christopher J. Mayer. "Equity and Time to Sale in the Real Estate Market." American Economic Review, 87(3), 1997, pp. 255-69.

Germaise, Mark J. and Tobias J. Moskowitz. "Confronting Information Asymmetries: Evidence from Real Estate Markets.” The Review of Financial Studies, 17(2), 2204, 405-437.

Grossman, Sanford J. and Oliver D. Hart. "An Analysis of the Principal-Agent Problem." Econometrica, 51(1), 1983, 7-45.

Gruber, Jonathan and Maria Owings. "Physician Financial Incentives and Cesarean Section Delivery." Rand Journal of Economics, 27(1), 1996, 99-123.

Hsieh, Chang-Tai and Enrico Moretti. "Can Free Entry Be Inefficient? Fixed Commissions and Social Waste in the Real Estate Industry." Journal of Political Economy, 111(5), 2003, 1076-1122.

Hubbard, Thomas. "An Empirical Examination of Moral Hazard in the Vehicle Inspection Market," RAND Journal of Economics, 29, 1998, 406-426.

Hubbard, Thomas N. "How Do Consumers Motivate Experts? Reputational Incentives in an Auto Repair Market." Journal of Law and Economics, 45(2), 2002, 437-68.

Jares, Timothy, James Larsen, and Thomas Zorn. "An Optimal Incentive System for Real Estate Agents.” Journal of Real Estate Research, 20(1-2), (July-Oct. 2000): 49-59.

Kennan, John and Robert Wilson. "Bargaining with Private Information." Journal of Economic Literature, 31(1), 1993, 45-104.

Krishna, Vijay and John Morgan. "A Model of Expertise.” Quarterly Journal of Economics, $116(2), 2001,747-75$.

Levy, Gilat. "Strategic Consultation in the Presence of Career Concerns." Mimeo, London School of Economics, 2000.

Merlo, Antonio and François Ortalo-Magné. "Bargaining over Residential Real Estate: Evidence from England.” Journal of Urban Economics, 56(2), 2004, 192-216.

Munneke, Henry, and Abdullah Yavas. "Incentives and Performance in Real Estate Brokerage." Journal of Real Estate Finance and Economics, 22, 2001, 5-21. 
Murphy, Kevin, and Robert Topel, 1990, "Efficiency Wages Reconsidered: Theory and Evidence," in Advances in the Theory and Measurement of Unemployment, edited by Yoram Weiss and Gideon Fishelson. London: Macmillan.

Prendergast, Canice. "The Tenuous Trade-Off between Risk and Incentives." Journal of Political Economy, 110(5), 2002, 1071-1102.

Riley, John G. "Silver Signals: Twenty-Five Years of Screening and Signaling." Journal of Economic Literature, 39(2), 2001, 432-78.

Sappington, David E. M. "Incentives in Principal-Agent Relationships." Journal of Economic Perspectives, 5(2), 1991, 45-66.

Shaban, Radwan. "Testing between Competing Models of Sharecropping." Journal of Political Economy, 95(5), 1987, 893-920.

Taylor, Curtis. "The Economics of Breakdowns, Checkups, and Cures.” Journal of Political Economy, 103(1), 1995, 53-74.

Taylor, Curtis. "Time-on-the-Market as a Sign of Quality." Review of Economic Studies, 66(3), 1999, 555-78. 
Table 1. Summary Statistics

\begin{tabular}{|c|c|c|c|c|c|c|c|}
\hline \multirow{2}{*}{\multicolumn{2}{|c|}{$\begin{array}{l}\text { (1) } \\
\text { Full sample } \\
\text { Mean Standard }\end{array}$}} & (3) & (4) & (5) & (6) & (7) & (8) \\
\hline & & \multicolumn{3}{|c|}{ Within city and year: } & & Within block: & \\
\hline Mean & $\begin{array}{l}\text { Standard } \\
\text { deviation }\end{array}$ & $\begin{array}{l}\text { Standard } \\
\text { deviation }\end{array}$ & $\begin{array}{l}\text { Mean agent- } \\
\text { owned } \\
\text { minus mean } \\
\text { non-agent- } \\
\text { owned }\end{array}$ & $\begin{array}{l}\text { p-value of } \\
\text { equality in } \\
\text { column (4) }\end{array}$ & $\begin{array}{l}\text { Standard } \\
\text { deviation }\end{array}$ & $\begin{array}{l}\text { Mean agent- } \\
\text { owned } \\
\text { minus mean } \\
\text { non-agent- } \\
\text { owned }\end{array}$ & $\begin{array}{l}\text { p-value of } \\
\text { equality in } \\
\text { column (7) }\end{array}$ \\
\hline
\end{tabular}

Realtor-owned home

0.034

0.181

Outcome variables

$$
\text { Sale price }
$$

Sale price (logged)

Days to sale

Agent Sales (logged)

Basic housing characteristics Number of bedrooms

$$
\text { Number of baths }
$$

Number of other rooms

Capacity of garage in cars

Indicators of housing quality Master bath

Central air

Other air

Fireplaces

Home age unknown

Home $0-5$ years old

Home 6-10 years old

Home 11-25 years old

Home 26-50 years old

Home 51-100 years old

Home $100+$ years old

271,405
12.33
93.62
3.146

216,797
0.577
118.6
1.392

151,330
0.335
113.3
1.348

57,591
0.128
24.18
-0.778

$<0.01$
$<0.01$
$<0.01$
$<0.01$

108,960
0.246
97.18
1.148

48,445

0.117

14.83

$-0.557$

$<0.01$

$<0.01$

$<0.01$

$<0.01$

$\begin{array}{llllllll}3.315 & 0.840 & 0.788 & 0.168 & <0.01 & 0.587 & 0.110 & <0.01 \\ 1.818 & 1.295 & 1.242 & 0.196 & <0.01 & 1.108 & 0.140 & <0.01 \\ 4.041 & 1.166 & 1.082 & 0.246 & <0.01 & 0.832 & 0.181 & <0.01 \\ 1.690 & 0.655 & 0.601 & 0.065 & <0.01 & 0.504 & 0.075 & <0.01\end{array}$

$\begin{array}{ll}0.354 & 0.478 \\ 0.733 & 0.442 \\ 0.106 & 0.308 \\ 0.619 & 0.733 \\ 0.115 & 0.318 \\ 0.010 & 0.102 \\ 0.018 & 0.135 \\ 0.071 & 0.257 \\ 0.496 & 0.500 \\ 0.273 & 0.445 \\ 0.017 & 0.130\end{array}$

0.427
0.389
0.299
0.639
0.228
0.101
0.133
0.246
0.437
0.383
0.127

0.088
0.013
-0.017
0.086
0.045
0.065
0.001
0.007
-0.084
-0.021
0.001

$<0.01$
0.047
$<0.01$
$<0.01$
$<0.01$
$<0.01$
0.674
0.105
$<0.01$
0.004
0.653

0.301
0.331
0.252
0.470
0.241
0.084
0.101
0.169
0.321
0.300
0.099

0.064

0.045

$-0.007$

0.062

$-0.011$

0.046

0.002

0.003

$-0.025$

$-0.009$

$-0.000$

$<0.01$

$<0.01$

0.107

$<0.01$

0.020

$<0.01$

0.355

0.299

$<0.01$

0.118

0.937 
Table 1 (Continued). Summary Statistics

\begin{tabular}{|c|c|c|c|c|c|c|c|c|}
\hline \multirow[b]{3}{*}{ Variable } & \multirow{2}{*}{\multicolumn{2}{|c|}{${ }^{(1)}$ Full sample ${ }^{(2)}$}} & (3) & (4) & (5) & \multirow[b]{3}{*}{$\begin{array}{l}\text { Standard } \\
\text { deviation }\end{array}$} & \multirow{3}{*}{$\begin{array}{c}(7) \\
\text { Within block: } \\
\text { Mean agent- } \\
\text { owned } \\
\text { minus mean } \\
\text { non-agent- } \\
\text { owned }\end{array}$} & \multirow{3}{*}{$\begin{array}{l}\text { (8) } \\
\text { p-value of } \\
\text { equality in } \\
\text { column (7) }\end{array}$} \\
\hline & & & \multicolumn{3}{|c|}{ Within city and year: } & & & \\
\hline & Mean & $\begin{array}{l}\text { Standard } \\
\text { deviation }\end{array}$ & $\begin{array}{l}\text { Standard } \\
\text { deviation }\end{array}$ & $\begin{array}{l}\text { Mean agent- } \\
\text { owned } \\
\text { minus mean } \\
\text { non-agent- } \\
\text { owned }\end{array}$ & $\begin{array}{l}\text { p-value of } \\
\text { equality in } \\
\text { column (4) }\end{array}$ & & & \\
\hline American four square style & 0.014 & 0.117 & 0.110 & 0.001 & 0.796 & 0.095 & 0.002 & 0.372 \\
\hline Bi-level style & 0.076 & 0.264 & 0.256 & -0.013 & $<0.01$ & 0.195 & -0.002 & 0.483 \\
\hline Bungalow style & 0.088 & 0.283 & 0.254 & -0.004 & 0.334 & 0.198 & -0.005 & 0.172 \\
\hline Cape Cod style & 0.067 & 0.250 & 0.243 & -0.010 & 0.014 & 0.191 & -0.002 & 0.471 \\
\hline Contemporary style & 0.027 & 0.163 & 0.158 & 0.002 & 0.517 & 0.125 & 0.000 & 0.985 \\
\hline Colonial style & 0.126 & 0.332 & 0.311 & 0.018 & $<0.01$ & 0.238 & 0.015 & 0.002 \\
\hline Cottage style & 0.010 & 0.101 & 0.099 & 0.001 & 0.784 & 0.081 & -0.000 & 0.799 \\
\hline English style & 0.019 & 0.138 & 0.136 & 0.000 & 0.991 & 0.117 & 0.002 & 0.402 \\
\hline Farmhouse style & 0.015 & 0.123 & 0.121 & -0.000 & 0.900 & 0.098 & -0.002 & 0.246 \\
\hline French provincial style & 0.005 & 0.067 & 0.067 & 0.004 & 0.035 & 0.056 & 0.002 & 0.163 \\
\hline Georgian style & 0.031 & 0.174 & 0.172 & 0.004 & 0.257 & 0.131 & 0.004 & 0.100 \\
\hline Other style & 0.016 & 0.127 & 0.126 & 0.000 & 0.848 & 0.108 & -0.003 & 0.092 \\
\hline Prairie style & 0.007 & 0.085 & 0.083 & 0.003 & 0.157 & 0.071 & 0.001 & 0.345 \\
\hline Quad-level style & 0.007 & 0.086 & 0.083 & 0.000 & 0.992 & 0.066 & -0.000 & 0.596 \\
\hline Queen Anne style & 0.006 & 0.078 & 0.077 & 0.003 & 0.103 & 0.067 & 0.002 & 0.194 \\
\hline Ranch style & 0.255 & 0.436 & 0.418 & -0.047 & $<0.01$ & 0.302 & -0.029 & $<0.01$ \\
\hline Step-up ranch style & 0.010 & 0.102 & 0.101 & -0.002 & 0.216 & 0.084 & -0.000 & 0.873 \\
\hline Traditional style & 0.023 & 0.151 & 0.147 & 0.020 & $<0.01$ & 0.125 & 0.016 & $<0.01$ \\
\hline Tri-level style & 0.044 & 0.204 & 0.201 & -0.008 & 0.012 & 0.162 & 0.000 & 0.938 \\
\hline Tudor style & 0.009 & 0.096 & 0.096 & 0.006 & $<0.01$ & 0.081 & 0.005 & $<0.01$ \\
\hline Victorian style & 0.018 & 0.133 & 0.130 & 0.010 & $<0.01$ & 0.099 & 0.004 & 0.086 \\
\hline Alum. or vinyl siding & 0.271 & 0.445 & 0.416 & 0.003 & 0.725 & 0.338 & 0.015 & 0.010 \\
\hline Brick siding & 0.509 & 0.500 & 0.461 & -0.004 & 0.610 & 0.354 & 0.016 & 0.014 \\
\hline Wood siding & 0.058 & 0.233 & 0.229 & -0.009 & 0.026 & 0.189 & -0.009 & 0.012 \\
\hline Stucco siding & 0.040 & 0.196 & 0.187 & -0.002 & 0.604 & 0.154 & -0.002 & 0.517 \\
\hline Other siding & 0.036 & 0.187 & 0.184 & 0.003 & 0.366 & 0.153 & 0.001 & 0.720 \\
\hline
\end{tabular}


Table 1 (Continued). Summary Statistics

\begin{tabular}{|c|c|c|c|c|c|c|c|c|}
\hline \multirow[b]{3}{*}{ Variable } & \multirow{2}{*}{\multicolumn{2}{|c|}{${ }^{(1)}$ Full sample ${ }^{(2)}$}} & \multirow{3}{*}{$\begin{array}{c}\text { (3) } \\
\text { Standard } \\
\text { deviation }\end{array}$} & \multirow{2}{*}{\multicolumn{2}{|c|}{$\begin{array}{l}\text { (4) } \\
\text { thin city and year: }\end{array}$}} & \multirow{3}{*}{$\begin{array}{c}(6) \\
\text { Standard } \\
\text { deviation }\end{array}$} & \multirow{3}{*}{$\begin{array}{c}(7) \\
\text { Within block: } \\
\text { Mean agent- } \\
\text { owned } \\
\text { minus mean } \\
\text { non-agent- } \\
\text { owned }\end{array}$} & \multirow{3}{*}{$\begin{array}{c}\text { (8) } \\
\text { p-value of } \\
\text { equality in } \\
\text { column (7) }\end{array}$} \\
\hline & & & & & & & & \\
\hline & Mean & $\begin{array}{l}\text { Standard } \\
\text { deviation }\end{array}$ & & $\begin{array}{l}\text { Mean agent- } \\
\text { owned } \\
\text { minus mean } \\
\text { non-agent- } \\
\text { owned } \\
\end{array}$ & $\begin{array}{l}\text { p-value of } \\
\text { equality in } \\
\text { column (4) }\end{array}$ & & & \\
\hline \multicolumn{9}{|l|}{ Keywords used to describe home } \\
\hline Needs updating & 0.002 & 0.050 & 0.050 & -0.001 & 0.481 & 0.043 & -0.000 & 0.545 \\
\hline Estate sale & 0.007 & 0.083 & 0.083 & -0.004 & $<0.01$ & 0.070 & -0.003 & $<0.01$ \\
\hline Foreclosure & 0.004 & 0.060 & 0.058 & -0.004 & $<0.01$ & 0.051 & -0.004 & $<0.01$ \\
\hline Handyman & 0.004 & 0.060 & 0.060 & -0.001 & 0.084 & 0.050 & -0.001 & 0.122 \\
\hline As-is & 0.076 & 0.265 & 0.262 & -0.029 & $<0.01$ & 0.224 & -0.020 & $<0.01$ \\
\hline Needs & 0.030 & 0.169 & 0.169 & -0.010 & $<0.01$ & 0.144 & -0.008 & $<0.01$ \\
\hline TLC & 0.012 & 0.107 & 0.107 & -0.005 & $<0.01$ & 0.091 & -0.005 & $<0.01$ \\
\hline Rehabber's & 0.003 & 0.053 & 0.053 & -0.002 & $<0.01$ & 0.044 & -0.002 & 0.044 \\
\hline Bank-owned & 0.001 & 0.036 & 0.035 & -0.001 & $<0.01$ & 0.030 & -0.001 & $<0.01$ \\
\hline Priced for a quick/Priced to sell & 0.026 & 0.158 & 0.158 & 0.003 & 0.274 & 0.136 & 0.005 & 0.056 \\
\hline Motivated & 0.017 & 0.129 & 0.128 & -0.000 & 0.980 & 0.110 & 0.002 & 0.317 \\
\hline Potential & 0.026 & 0.160 & 0.159 & -0.012 & $<0.01$ & 0.137 & -0.011 & $<0.01$ \\
\hline Youthful & 0.002 & 0.040 & 0.040 & -0.001 & $<0.01$ & 0.036 & -0.001 & 0.066 \\
\hline Close & 0.078 & 0.268 & 0.266 & 0.002 & 0.639 & 0.228 & 0.008 & 0.069 \\
\hline$!$ & 0.493 & 0.500 & 0.491 & -0.025 & $<0.01$ & 0.422 & -0.011 & 0.125 \\
\hline New & 0.558 & 0.497 & 0.489 & 0.066 & $<0.01$ & 0.417 & 0.065 & $<0.01$ \\
\hline Spacious & 0.142 & 0.350 & 0.346 & -0.043 & $<0.01$ & 0.295 & -0.023 & $<0.01$ \\
\hline Elegance & 0.025 & 0.155 & 0.154 & 0.003 & 0.364 & 0.129 & 0.003 & 0.245 \\
\hline Beautiful & 0.222 & 0.416 & 0.413 & -0.024 & $<0.01$ & 0.354 & -0.011 & 0.088 \\
\hline Appealing & 0.003 & 0.057 & 0.057 & -0.002 & $<0.01$ & 0.050 & -0.002 & $<0.01$ \\
\hline Renovated / Remodeled & 0.082 & 0.275 & 0.272 & 0.036 & $<0.01$ & 0.234 & 0.034 & $<0.01$ \\
\hline Vintage & 0.014 & 0.118 & 0.117 & -0.007 & $<0.01$ & 0.101 & -0.006 & $<0.01$ \\
\hline State-of-the-art & 0.002 & 0.042 & 0.041 & 0.001 & 0.424 & 0.035 & 0.001 & 0.259 \\
\hline Maintained & 0.083 & 0.276 & 0.275 & -0.034 & $<0.01$ & 0.236 & -0.020 & $<0.01$ \\
\hline Wonderful & 0.073 & 0.260 & 0.257 & -0.025 & $<0.01$ & 0.222 & -0.015 & $<0.01$ \\
\hline
\end{tabular}


Table 1 (Continued). Summary Statistics

\begin{tabular}{|c|c|c|c|c|c|c|c|c|}
\hline \multirow[b]{3}{*}{ Variable } & \multirow{2}{*}{\multicolumn{2}{|c|}{${ }^{(1)}$ Full sample }} & \multirow{3}{*}{$\begin{array}{c}\text { (3) } \\
\text { Standard } \\
\text { deviation }\end{array}$} & \multirow{2}{*}{\multicolumn{2}{|c|}{$\begin{array}{l}\text { (4) } \\
\text { Vithin city and year: }\end{array}$}} & \multirow{3}{*}{$\begin{array}{c}\text { (6) } \\
\text { Standard } \\
\text { deviation }\end{array}$} & \multirow{3}{*}{$\begin{array}{c}(7) \\
\text { Within block: } \\
\text { Mean agent- } \\
\text { owned } \\
\text { minus mean } \\
\text { non-agent- } \\
\text { owned }\end{array}$} & \multirow{3}{*}{$\begin{array}{l}\text { (8) } \\
\text { p-value of } \\
\text { equality in } \\
\text { column (7) }\end{array}$} \\
\hline & & & & & & & & \\
\hline & Mean & $\begin{array}{l}\text { Standard } \\
\text { deviation }\end{array}$ & & $\begin{array}{l}\text { Mean agent- } \\
\text { owned } \\
\text { minus mean } \\
\text { non-agent- } \\
\text { owned }\end{array}$ & $\begin{array}{l}\text { p-value of } \\
\text { equality in } \\
\text { column (4) }\end{array}$ & & & \\
\hline Brand new & 0.021 & 0.143 & 0.143 & 0.013 & $<0.01$ & 0.124 & 0.010 & $<0.01$ \\
\hline Fantastic & 0.018 & 0.133 & 0.133 & -0.003 & 0.133 & 0.113 & -0.003 & 0.126 \\
\hline Charming & 0.138 & 0.345 & 0.338 & -0.027 & $<0.01$ & 0.281 & -0.022 & $<0.01$ \\
\hline Stunning & 0.021 & 0.143 & 0.143 & 0.009 & $<0.01$ & 0.122 & 0.008 & $<0.01$ \\
\hline Amazing & 0.002 & 0.039 & 0.039 & -0.001 & $<0.01$ & 0.034 & -0.001 & 0.027 \\
\hline Granite & 0.020 & 0.142 & 0.137 & 0.044 & $<0.01$ & 0.119 & 0.033 & $<0.01$ \\
\hline Immaculate & 0.027 & 0.163 & 0.163 & -0.010 & $<0.01$ & 0.138 & -0.005 & $<0.01$ \\
\hline Breathtaking & 0.003 & 0.056 & 0.056 & 0.002 & 0.110 & 0.046 & 0.001 & 0.256 \\
\hline Neighborhood & 0.038 & 0.191 & 0.189 & -0.011 & $<0.01$ & 0.162 & -0.008 & $<0.01$ \\
\hline Spectacular & 0.015 & 0.120 & 0.119 & 0.004 & 0.086 & 0.101 & 0.004 & 0.061 \\
\hline Landscaped & 0.085 & 0.278 & 0.276 & -0.008 & 0.088 & 0.237 & 0.002 & 0.634 \\
\hline Art Glass & 0.005 & 0.071 & 0.068 & -0.002 & 0.117 & 0.063 & -0.002 & 0.083 \\
\hline Built-in & 0.063 & 0.242 & 0.240 & -0.008 & 0.051 & 0.207 & -0.005 & 0.180 \\
\hline Tasteful & 0.015 & 0.120 & 0.120 & -0.004 & 0.034 & 0.105 & -0.002 & 0.145 \\
\hline Must see & 0.037 & 0.189 & 0.188 & 0.008 & 0.028 & 0.161 & 0.007 & 0.033 \\
\hline Fabulous & 0.039 & 0.193 & 0.190 & -0.001 & 0.681 & 0.163 & 0.001 & 0.805 \\
\hline Leaded & 0.013 & 0.114 & 0.113 & 0.002 & 0.369 & 0.098 & 0.002 & 0.362 \\
\hline Delightful & 0.012 & 0.107 & 0.106 & -0.004 & $<0.01$ & 0.092 & -0.004 & 0.012 \\
\hline Move-in & 0.079 & 0.271 & 0.269 & 0.018 & $<0.01$ & 0.233 & 0.022 & $<0.01$ \\
\hline Gourmet & 0.019 & 0.135 & 0.134 & 0.013 & $<0.01$ & 0.111 & 0.010 & $<0.01$ \\
\hline Copper & 0.009 & 0.095 & 0.095 & 0.000 & 0.855 & 0.082 & 0.001 & 0.546 \\
\hline Corian & 0.016 & 0.126 & 0.125 & -0.000 & 0.998 & 0.106 & 0.001 & 0.730 \\
\hline Custom & 0.082 & 0.274 & 0.272 & 0.029 & $<0.01$ & 0.226 & 0.020 & $<0.01$ \\
\hline Unique & 0.017 & 0.130 & 0.130 & 0.002 & 0.409 & 0.109 & 0.004 & 0.067 \\
\hline Maple & 0.021 & 0.145 & 0.143 & 0.023 & $<0.01$ & 0.126 & 0.020 & $<0.01$ \\
\hline Newer & 0.256 & 0.436 & 0.430 & -0.037 & $<0.01$ & 0.369 & -0.012 & 0.050 \\
\hline
\end{tabular}


Table 1 (Continued). Summary Statistics

\begin{tabular}{|c|c|c|c|c|c|c|c|c|}
\hline \multirow[b]{3}{*}{ Variable } & (1) & (2) & (3) & (4) & (5) & \multirow[b]{3}{*}{$\begin{array}{l}\text { Standard } \\
\text { deviation }\end{array}$} & \multirow{3}{*}{$\begin{array}{c}(7) \\
\text { Within block: } \\
\text { Mean agent- } \\
\text { owned } \\
\text { minus mean } \\
\text { non-agent- } \\
\text { owned }\end{array}$} & \multirow[b]{3}{*}{$\begin{array}{l}\text { p-value of } \\
\text { equality in } \\
\text { column (7) }\end{array}$} \\
\hline & \multicolumn{2}{|c|}{ Full sample } & \multicolumn{3}{|c|}{ Within city and year: } & & & \\
\hline & Mean & $\begin{array}{l}\text { Standard } \\
\text { deviation }\end{array}$ & $\begin{array}{l}\text { Standard } \\
\text { deviation }\end{array}$ & $\begin{array}{l}\text { Mean agent- } \\
\text { owned } \\
\text { minus mean } \\
\text { non-agent- } \\
\text { owned }\end{array}$ & $\begin{array}{l}\text { p-value of } \\
\text { equality in } \\
\text { column (4) }\end{array}$ & & & \\
\hline Hurry & 0.018 & 0.131 & 0.130 & -0.001 & 0.517 & 0.113 & 0.000 & 0.903 \\
\hline Pride & 0.017 & 0.130 & 0.129 & -0.007 & $<0.01$ & 0.111 & -0.004 & $<0.01$ \\
\hline Clean & 0.049 & 0.217 & 0.213 & -0.005 & 0.112 & 0.183 & -0.004 & 0.225 \\
\hline Quiet & 0.048 & 0.214 & 0.212 & -0.001 & 0.748 & 0.176 & -0.001 & 0.784 \\
\hline Dream & 0.017 & 0.128 & 0.127 & 0.000 & 0.982 & 0.107 & -0.002 & 0.243 \\
\hline Block & 0.034 & 0.182 & 0.180 & 0.003 & 0.461 & 0.156 & 0.005 & 0.088 \\
\hline Huge & 0.128 & 0.334 & 0.330 & 0.007 & 0.215 & 0.279 & 0.008 & 0.101 \\
\hline Deck & 0.161 & 0.368 & 0.364 & 0.005 & 0.416 & 0.307 & 0.011 & 0.041 \\
\hline Mint & 0.013 & 0.115 & 0.114 & -0.004 & 0.017 & 0.098 & -0.003 & 0.035 \\
\hline Stately & 0.007 & 0.084 & 0.084 & 0.001 & 0.537 & 0.071 & 0.000 & 0.782 \\
\hline
\end{tabular}

Notes: Summary statistics reflect our sample of roughly 98,038 single-family home sales over the period 1992-2002 in 34 Cook County, Illinois suburbs. Homes sold without real-estate agents are excluded from the sample, as are homes that are listed on the Multiple Listing Service but do not sell, and Multiple Listing Service entries with data errors or inconsistencies. All variables included in the data are self-reported by the real-estate agent listing a home for sale. The

keywords are taken from the written description of the home included in the listing. Columns 1 and 2 report information for raw data covering the whole sample. Columns 3-6 present information after removing city-fixed effects and year-fixed effects. Columns 6-8 remove year-fixed effects and city-block fixed effects. 
Table 2. The Impact of Agent-Ownership Status on Sale Price and Time to Sale

(1) (2) (3) (4)

Dependent Variable: $\ln$ (Sale Price of Home)

\begin{tabular}{ccccc}
\hline $\begin{array}{c}\text { Coefficient on Agent-Owned Home } \\
\text { (Standard Error) }\end{array}$ & 0.048 & 0.042 & 0.038 & 0.037 \\
\hline $\mathrm{R}^{2}$ & $(0.004)$ & $(0.004)$ & $(0.004)$ & $(0.003)$ \\
\hline \hline
\end{tabular}

Dependent Variable: Time to Sale (in Days)

\begin{tabular}{ccccc}
\hline & \multicolumn{4}{c}{ Dependent Variable: Time to Sale (in Days) } \\
\hline $\begin{array}{c}\text { Coefficient on Agent-Owned Home } \\
\text { (Standard Error) }\end{array}$ & 16.89 & 11.03 & 10.25 & 9.47 \\
$\mathrm{R}^{2}$ & $(2.42)$ & $(2.40)$ & $(2.39)$ & $(2.25)$ \\
\hline \hline
\end{tabular}

\author{
Controls Included: \\ City*Year Interactions \\ Basic House Characteristics \\ Indicators of House Quality \\ Keywords in Description \\ Block Fixed Effects
}

Implied Informational Rent of Agent

Assuming a $20 \%$ annual discount rate

\begin{abstract}
Notes: Regression coefficients are reported in the table, along with standard errors in parentheses. Results are based on a sample of 98,038 single-family home sales in 34 Cook County, Illinois suburbs over the period 1992-2002. The dependent variable in the top panel of the table is the natural log of the sale price; the dependent variable in the bottom panel is the number of days on the market. Each coefficient reported in the table is from a separate regression. The other variables included in each specification are noted in the table, but the coefficients on these other variables are not reported in the table. Table 3 presents full regression results for the third column of this table. The bottom row of the table reports the implied informational rent accruing to agents selling their own homes, under the assumption of a 20 percent annual discount rate. The informational rent is computed as the additional price received for a home adjusted for the extra time on the market.
\end{abstract}


Table 3. Full Regression Results (Specification Includes Block-Level Fixed Effects)

\begin{tabular}{|c|c|c|c|c|}
\hline \multirow{2}{*}{ Explanatory Variable $\quad$ Dependent Variable: } & \multicolumn{2}{|c|}{$\ln ($ Sale Price $)$} & \multicolumn{2}{|c|}{ Days to Sale } \\
\hline & Coeff. & S.E. & Coeff. & S.E. \\
\hline Agent-owned & 0.037 & 0.003 & 9.47 & 2.25 \\
\hline \multicolumn{5}{|l|}{ Bedrooms ( 1 bedroom omitted): } \\
\hline 2 bedrooms & 0.177 & 0.013 & 5.02 & 10.77 \\
\hline 3 bedrooms & 0.264 & 0.013 & 13.85 & 10.76 \\
\hline 4 bedrooms & 0.325 & 0.013 & 25.10 & 10.81 \\
\hline 5 bedrooms & 0.378 & 0.013 & 36.64 & 10.95 \\
\hline $6+$ bedrooms & 0.422 & 0.014 & 38.70 & 11.46 \\
\hline \multicolumn{5}{|l|}{ Rooms (not bed or bath, 7 or more omitted): } \\
\hline 1 additional room & -0.216 & 0.006 & -30.09 & 4.60 \\
\hline 2 additional rooms & -0.196 & 0.005 & -27.56 & 4.29 \\
\hline 3 additional rooms & -0.158 & 0.005 & -22.23 & 4.21 \\
\hline 4 additional rooms & -0.126 & 0.005 & -16.54 & 4.20 \\
\hline 5 additional rooms & -0.090 & 0.005 & -10.76 & 4.29 \\
\hline 6 additional rooms & -0.054 & 0.006 & -10.44 & 4.80 \\
\hline \multicolumn{5}{|l|}{ Bathrooms ( 4 or more omitted): } \\
\hline 1.0 bath & -0.384 & 0.005 & -48.79 & 4.05 \\
\hline 1.5 baths & -0.333 & 0.005 & -46.40 & 3.89 \\
\hline 2.0 baths & -0.319 & 0.005 & -44.53 & 3.77 \\
\hline 2.5 baths & -0.234 & 0.004 & -38.52 & 3.52 \\
\hline 3.0 baths & -0.239 & 0.005 & -32.32 & 3.78 \\
\hline 3.5 baths & -0.115 & 0.004 & -25.79 & 3.45 \\
\hline \multicolumn{5}{|l|}{ Cars (4 or more omitted): } \\
\hline 1 car garage & -0.111 & 0.004 & -25.17 & 2.90 \\
\hline 2 car garage & -0.093 & 0.003 & -14.66 & 2.45 \\
\hline 3 car garage & -0.056 & 0.003 & -14.17 & 2.27 \\
\hline \multicolumn{5}{|l|}{ Age (0-5 years old omitted): } \\
\hline Unknown & -0.096 & 0.005 & -39.21 & 4.41 \\
\hline $6-10$ years old & -0.092 & 0.007 & -41.92 & 5.36 \\
\hline $11-25$ years old & -0.153 & 0.006 & -41.29 & 4.69 \\
\hline $26-50$ years old & -0.187 & 0.005 & -45.82 & 4.34 \\
\hline $51-100$ years old & -0.167 & 0.005 & -47.53 & 4.33 \\
\hline $100+$ years old & -0.141 & 0.007 & -42.15 & 5.59 \\
\hline \multicolumn{5}{|l|}{ Fireplaces ( 4 or more omitted): } \\
\hline 1 fireplace & -0.188 & 0.004 & -20.52 & 3.54 \\
\hline 2 fireplaces & -0.144 & 0.004 & -17.27 & 3.42 \\
\hline 3 fireplaces & -0.095 & 0.004 & -14.10 & 3.46 \\
\hline American four square & 0.028 & 0.005 & -0.06 & 3.95 \\
\hline Bi-level & 0.000 & 0.003 & 5.32 & 2.16 \\
\hline Bungalow & -0.030 & 0.003 & -1.86 & 2.18 \\
\hline Cape Cod & -0.015 & 0.003 & -3.68 & 2.20 \\
\hline Contemporary & 0.012 & 0.004 & 16.47 & 3.05 \\
\hline Colonial & 0.056 & 0.002 & 4.97 & 1.92 \\
\hline Cottage & -0.049 & 0.006 & 4.65 & 4.50 \\
\hline English & 0.057 & 0.004 & 1.14 & 3.26 \\
\hline Farmhouse & -0.009 & 0.005 & 0.54 & 3.86 \\
\hline French provincial & 0.111 & 0.008 & 14.61 & 6.36 \\
\hline Georgian & 0.031 & 0.004 & 3.16 & 2.95 \\
\hline Other & 0.011 & 0.004 & 14.51 & 3.44 \\
\hline Prairie & 0.089 & 0.006 & 16.16 & 5.13 \\
\hline Quad-level & -0.001 & 0.007 & -5.30 & 5.39 \\
\hline
\end{tabular}


Table 3 (Continued). Full Regression Results (Includes Block-Level Fixed Effects)

\begin{tabular}{|c|c|c|c|c|}
\hline \multirow{2}{*}{ 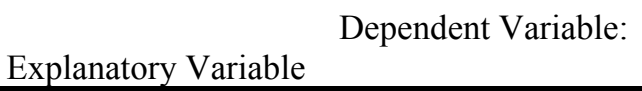 } & \multicolumn{2}{|c|}{$\ln ($ Sale Price $)$} & \multicolumn{2}{|c|}{ Days to Sale } \\
\hline & Coeff. & S.E. & Coeff. & S.E. \\
\hline \multicolumn{5}{|l|}{ Style (continued): } \\
\hline Queen Anne & 0.013 & 0.007 & -2.75 & 5.36 \\
\hline Ranch & -0.029 & 0.002 & -0.20 & 1.70 \\
\hline Step-up ranch & -0.012 & 0.005 & 4.00 & 4.32 \\
\hline Traditional & 0.065 & 0.004 & 14.90 & 3.05 \\
\hline Tri-level & -0.013 & 0.003 & 6.99 & 2.46 \\
\hline Tudor & 0.066 & 0.006 & 15.05 & 4.49 \\
\hline Victorian & 0.054 & 0.005 & 8.90 & 3.97 \\
\hline \multicolumn{5}{|l|}{ Siding: } \\
\hline Brick & 0.033 & 0.002 & 10.07 & 1.94 \\
\hline Aluminum or Vinyl & -0.001 & 0.002 & 11.59 & 1.98 \\
\hline Wood & -0.003 & 0.003 & 8.94 & 2.48 \\
\hline Stucco & 0.010 & 0.003 & 3.15 & 2.82 \\
\hline Other & 0.022 & 0.003 & 11.53 & 2.81 \\
\hline \multicolumn{5}{|l|}{ Misc. quality: } \\
\hline Central Air & 0.068 & 0.002 & 0.58 & 1.41 \\
\hline Other Air & 0.030 & 0.002 & 4.20 & 1.70 \\
\hline Master Bedroom Bath & 0.044 & 0.002 & 1.83 & 1.41 \\
\hline Agent Sales (logged) & 0.003 & 0.000 & -2.03 & 0.31 \\
\hline \multicolumn{5}{|l|}{ Descriptions: } \\
\hline Needs updating & 0.004 & 0.010 & -15.52 & 8.45 \\
\hline Estate sale & -0.017 & 0.006 & -23.27 & 4.97 \\
\hline Foreclosure & -0.144 & 0.009 & 18.68 & 7.08 \\
\hline Handyman & -0.131 & 0.009 & -26.46 & 7.03 \\
\hline As-is & -0.062 & 0.002 & -7.29 & 1.66 \\
\hline Needs & -0.062 & 0.003 & -1.99 & 2.78 \\
\hline TLC & -0.032 & 0.005 & -1.86 & 4.14 \\
\hline Rehabber's & -0.081 & 0.010 & -4.61 & 7.87 \\
\hline Bank-owned & -0.085 & 0.014 & 37.23 & 11.65 \\
\hline Priced for a quick/Priced to sell & -0.025 & 0.003 & -3.44 & 2.59 \\
\hline Motivated & -0.025 & 0.004 & 55.42 & 3.17 \\
\hline Potential & -0.034 & 0.003 & 2.74 & 2.56 \\
\hline Youthful & 0.012 & 0.012 & -15.57 & 9.74 \\
\hline Close & -0.011 & 0.002 & 4.44 & 1.52 \\
\hline$!$ & -0.001 & 0.001 & 4.63 & 0.84 \\
\hline New & 0.007 & 0.001 & 3.53 & 0.99 \\
\hline Spacious & -0.005 & 0.001 & 4.51 & 1.18 \\
\hline Elegance & 0.054 & 0.003 & 1.42 & 2.71 \\
\hline Beautiful & 0.020 & 0.001 & -2.55 & 1.00 \\
\hline Appealing & 0.011 & 0.008 & -8.27 & 6.86 \\
\hline Renovated / Remodeled & 0.014 & 0.002 & -3.25 & 1.49 \\
\hline Vintage & 0.013 & 0.004 & -2.37 & 3.47 \\
\hline State-of-the-art & 0.079 & 0.012 & -20.70 & 9.88 \\
\hline Maintained & 0.004 & 0.002 & -6.41 & 1.48 \\
\hline Wonderful & 0.009 & 0.002 & -5.64 & 1.57 \\
\hline Brand new & -0.005 & 0.003 & 4.72 & 2.81 \\
\hline Fantastic & 0.001 & 0.004 & -1.91 & 3.05 \\
\hline Charming & -0.001 & 0.002 & -6.78 & 1.27 \\
\hline Stunning & 0.047 & 0.004 & -7.96 & 2.86 \\
\hline Amazing & -0.010 & 0.012 & 5.57 & 10.11 \\
\hline Granite & 0.093 & 0.004 & 12.27 & 3.07 \\
\hline
\end{tabular}


Table 3 (Continued). Full Regression Results (Includes Block-Level Fixed Effects)

\begin{tabular}{|c|c|c|c|c|}
\hline \multirow{2}{*}{ Explanatory Variable $\quad$ Dependent Variable: } & \multicolumn{2}{|c|}{$\ln ($ Sale Price $)$} & \multicolumn{2}{|c|}{ Days to Sale } \\
\hline & Coeff. & S.E. & Coeff. & S.E. \\
\hline \multicolumn{5}{|l|}{ Descriptions (continued): } \\
\hline Immaculate & 0.018 & 0.003 & -12.69 & 2.51 \\
\hline Breathtaking & 0.076 & 0.009 & 3.73 & 7.49 \\
\hline Neighborhood & -0.014 & 0.003 & 1.82 & 2.16 \\
\hline Spectacular & 0.057 & 0.004 & 0.67 & 3.45 \\
\hline Landscaped & 0.021 & 0.002 & -6.43 & 1.48 \\
\hline Art Glass & 0.031 & 0.007 & -13.15 & 5.53 \\
\hline Built-in & 0.004 & 0.002 & -4.93 & 1.68 \\
\hline Tasteful & 0.018 & 0.004 & -10.63 & 3.31 \\
\hline Must see & 0.007 & 0.003 & 0.82 & 2.16 \\
\hline Fabulous & 0.029 & 0.003 & -1.68 & 2.14 \\
\hline Leaded & 0.038 & 0.004 & -6.73 & 3.56 \\
\hline Delightful & -0.002 & 0.005 & -3.35 & 3.76 \\
\hline Move-in & 0.008 & 0.002 & -2.63 & 1.50 \\
\hline Gourmet & 0.062 & 0.004 & 9.25 & 3.17 \\
\hline Copper & 0.025 & 0.005 & -2.23 & 4.22 \\
\hline Corian & 0.042 & 0.004 & -7.09 & 3.29 \\
\hline Custom & 0.033 & 0.002 & 0.49 & 1.55 \\
\hline Unique & 0.016 & 0.004 & 0.84 & 3.18 \\
\hline Maple & 0.021 & 0.003 & 0.63 & 2.82 \\
\hline Newer & -0.011 & 0.001 & -0.22 & 1.10 \\
\hline Hurry & 0.000 & 0.004 & -2.58 & 3.10 \\
\hline Pride & 0.016 & 0.004 & -7.27 & 3.11 \\
\hline Clean & 0.000 & 0.002 & -3.47 & 1.90 \\
\hline Quiet & -0.006 & 0.002 & 2.13 & 1.98 \\
\hline Dream & 0.037 & 0.004 & -2.31 & 3.25 \\
\hline Block & -0.006 & 0.003 & 3.59 & 2.22 \\
\hline Huge & 0.004 & 0.002 & 4.43 & 1.25 \\
\hline Deck & 0.010 & 0.001 & 0.50 & 1.15 \\
\hline Mint & 0.018 & 0.004 & -11.15 & 3.52 \\
\hline Stately & 0.048 & 0.006 & 2.82 & 4.89 \\
\hline \multicolumn{5}{|l|}{ Listing year (1993 omitted): } \\
\hline 1992 & -0.042 & 0.003 & 2.52 & 2.29 \\
\hline 1994 & 0.025 & 0.003 & 23.61 & 2.26 \\
\hline 1995 & 0.045 & 0.003 & 19.78 & 2.24 \\
\hline 1996 & 0.062 & 0.003 & 12.24 & 2.23 \\
\hline 1997 & 0.078 & 0.003 & 8.23 & 2.23 \\
\hline 1998 & 0.129 & 0.003 & -19.06 & 2.22 \\
\hline 1999 & 0.204 & 0.003 & -42.32 & 2.26 \\
\hline 2000 & 0.301 & 0.003 & -44.59 & 2.28 \\
\hline 2001 & 0.391 & 0.003 & -34.24 & 2.27 \\
\hline 2002 & 0.475 & 0.003 & -36.47 & 2.28 \\
\hline
\end{tabular}

Notes: Table 3 reports the full coefficient for the specifications shown in column 4 of Table 2. See the notes to Table 2 for further details. All keyword descriptions are entered as indicator variables equal to one if the word is used at least once in the listing and zero otherwise. 
Table 4. The Impact of Agent Ownership by Sub-sample (Values in table are coefficient on agent-owned indicator variable)

\begin{tabular}{|c|c|c|c|c|}
\hline Sub-sample & $\begin{array}{c}\text { Magnitude } \\
\text { of } \\
\text { predicted } \\
\text { agent- } \\
\text { owned } \\
\text { distortion }\end{array}$ & $\begin{array}{c}\text { Dependent } \\
\text { variable: } \\
\ln (\text { Sale Price })\end{array}$ & $\begin{array}{c}\text { Dependent } \\
\text { variable: } \\
\text { Days to Sale }\end{array}$ & $\begin{array}{c}\text { Implied } \\
\text { information } \\
\text { advantage } \\
\text { (20\% annual } \\
\text { discount rate) }\end{array}$ \\
\hline
\end{tabular}

A. Heterogeneity of housing
stock on the block

High heterogeneity

High

0.043

9.45

0.038

Moderate heterogeneity

Medium

$(0.005)$

$(3.68)$

Moderate heterogeneity

Low heterogeneity

Low

0.039

11.92

0.032

(0.005)

(3.82)

0.023

5.09

0.020

(0.005)

(4.24)

B. Time period

On the market 1992-1995

High

0.049

15.20

0.041

On the market 1996-1999

Medium

$(0.007)$

(6.11)

7.99

(4.14)

On the market 2000-2002

Low

(0.005)

2.47

(3.98)

0.028

0.029

0.028

(0.006)

C. Buyer's agent presence

Buyer's agent absent * agent-owned home

Buyer's agent present * agent-owned home

$\begin{array}{lccc}\text { High } & 0.052 & \text { N/A } & \text { N/A } \\ \text { Low } & (0.007) & & \\ & 0.033 & \text { N/A } & \text { N/A }\end{array}$

Notes: All coefficients in the table correspond to variations on the specification reported in column 4 of Table 2. Panels A and B divide the sample in to mutually exclusive, exhaustive sub-samples. The heterogeneity of a city block's housing stock is computed based on the Herfindahl index of styles of houses sold on the block in our sample period (e.g. Victorian, Georgian, colonial, etc.). Blocks with fewer than three home sales over the course of the sample are excluded from the analysis in Panel A. The remaining sample is divided into equally sized groups based on the Herfindahl measure. Panel B divides the sample according to the year that a house is originally listed for sale. Panel $\mathrm{C}$ adds interactions between whether a buyer's agent is part of the transaction and the agent-owned variable to the baseline specification. 